\title{
The Value of Adenosine Deaminase Enzime Level in the Positive Diagnosis of Tuberculous Pleural Effusion
}

\begin{abstract}
VIORICA COJ OCARU'1, ELENA DANTES $1,2 *$, MARIANA GABRIELA NOVAC ${ }^{1}$, ALEXANDRA MARIA IONESCU1, EDITH SIMONA IANOSI ${ }^{3}$, ELENA RUSU ${ }^{4}$, ROXANA MARIA NEMES ${ }^{4,5}$

${ }^{1}$ Clinical Pneumophthisiology Hospital of Constanta, 40 Sentinelei Str., 900002, Constanta, Romania

2 20vidius University of Constana, Medicine Faculty, $4^{\text {th }}$ Clinical Department, 124, Mamaia Blvd, 900527, Constanta, Romania; 3University of Medicine and Pharmacy Targu Mures, Department of Pulmonology, 38 Gheorghe Marinescu Blvd., 540139, Targu Mures, Romania

${ }^{4}$ Titu Maiorescu University, Faculty of Medicine, 67A Gheorghe Petrascu, 031593, Bucharest, Romania

IInstitute of Pulmonology, Marius Nasta, 5 Viilor Road, 050151, Bucharest, Romania

The etiologic diagnosis of pleural effusion is often difficult, requiring invasive investigations to determine it. In Romania, tuberculosis is a frequent cause of pleural effusion, with the diagnosis of certainty being based on the bacteriological or histopathological examination. Adenosine deaminase (ADA) is an enzyme found in Tlymphocytes, stimulated by Mycobacterium tuberculosis, which is why it is considered to be an essential marker of etiologic diagnosis in countries where the TB endemic is elevated. A case-control study was conducted in the Clinical Pneumophthisiology Hospital of Constanta, Romania, in patients diagnosed with tuberculous pleural effusion. The primary endpoint was to establish the cut-off value for ADA in supporting the positive diagnosis of TB pleural effusion, and the secondary objective was to identify the differences between TB pleural effusion and other etiologic types of pleural effusion. A cut-off of $55 \mathrm{UI}$ has a good specificity (80\%) and good sensitivity (85\%). The study confirms other features of tuberculous pleural effusion as younger age, lower levels of white blood cells and-neutrophils, increased number of lymphocytes in pleural fluid, low protein serum level, increased values of pleural lactic dehydrogenase (LDH) and pleural $A D A$.
\end{abstract}

Keywords: adenosin deaminase (ADA), pleural effusion, tuberculosis

Currently, the trend in medical research is to search for biochemical, molecular or immunological markers to support a positive diagnosis of disease by less invasive and less expensive methods. Such an approach is found in the etiologic diagnosis of pleural effusion, which is difficult in most cases. Classical non-invasive methods have little sensitivity and specificity in supporting the cause of pleural effusion [1]. Although the Light's criteria retain their importance over time, making it possible to differentiate an exudative pleural effusion from a transudate, they offer no help in discriminating between the infectious, tuberculous (TB), or malignantnature of a pleural effusion. Of course, a certain diagnosis can be achieved by bacteriologically positive examination for Mycobacterium tuberculosis (MTB) or by a pleural biopsy performed blind, or by thoracoscopy procedure. Bacteriological confirmation of TB through culture is possible in only $25 \%$ of cases and the biopsy test can reveal caseous epithelioid granulomas in $80 \%$ of cases. However, these investigations are not always available [2].

As the TB endemic burden remains high in Romania, TB pleural effusion is common, being the second location as frequency after pulmonary tuberculosis [3]. For diagnosis of TB serositis, as pleural effusion or pericarditis, age, history of the disease including contact with a contagious patient, biochemical, bacteriological and cytological examination of the pleural and pericardial fluid, histopathological examination are taken into account [4]. The value of proteins, LDH, glucose in the pleural fluid, and the serum value ratio may suggest but cannot support the diagnosis of tuberculosis.

Adenosine deaminase (ADA) studies have shown promising results in the diagnosis of TB pleural effusion.

* email: elena.dantes@gmail.com, Phone: (+)4 0744646233
The interest is even greater for a non-invasive, not expensive, affordable, high-sensitivity and high-specific test [5]. Thus, more and more publications are trying to determine the cut-off value for this enzyme to be considered a diagnostic marker for tuberculosis. This enzyme is normally found in the cells of the body, but the highest concentrations are found in Tlymphocytes because they are stimulated by the presence of TB bacilli in cells. Increased ADA is considered a marker of activation of T lymphocytes and cellular immunity [5, 6]. ADA plays a role in the purine catabolic pathway and catalyzes the deamination reaction from adenosine to inosine [5]. The chemical reactions in which ADA has a role are:

-the enzymatic deamination of adenosine to inosine,

-purine nucleoside phosphorylase (PNP) convert adenosine to hypoxanthine,

-xanthine oxidase (XOD) converts hypoxanthine to uric acid and hydrogen peroxide $\left(\mathrm{H}_{2} \mathrm{O}_{2}\right)$,

-in the presence of peroxidase (POD), $\mathrm{H}_{2} \mathrm{O}_{2}$ react with $\mathrm{N}$-Ethyl-N-(2-hydroxy-3-sulfopropyl) - 3-methylaniline (EHSPT) and 4-aminoantipyrine (4-AA) to generate quinone dye,

-quinone dye is monitored in a kinetic manner [7].

Although two isoforms are known: ADA 1 and ADA 2 (which is more specific and found only in monocytes and macrophages), in clinical practice the ADA activity is measured overall [8-10].

\section{Experimental part}

A case control study was conducted to evaluate the cut-off value for ADA in the pleural fluid and its contribution to supporting the diagnosis of TB pleural effusion in patients registered in Constanta Pneumophthisiology Clinical 
Hospital database, between September 2015 and December 2017. The socio-demographic, biological and bacteriological outcomes of inpatients with pleural effusion were analyzed among cases with TB pleural effusions $(n=114)$ comparing to controls $(n=330)$ with other types of pleural effusion. After signing their consent, all patients underwent thoracentesis. Laboratory blood tests and pleural fluid analysis for ADA, albumin, cytology, acid-fast bacilli (AFB) smear, identification of MTB in liquid BACTEC MGIT 960 and solid Lowenstein Jensen culture were performed in all cases.

\section{Method}

ADA measurement is based on colorimetric techniques. One unit of ADA is defined as the amount of ADA that generates 1 imole of inosine resulted from adenosine per minute, at 37 degree Celsius [5]. Work technique of the colorimetric ADA assay was described by Guisti and Galanti [6]. After taking samples of the pleural fluid, ADA was immediately tested to prevent dropping of enzyme over time, if it is kept at ambient temperature [5,7]. If desired, the sample may be kept cold, or the sample may require an addition of glycerol and sodium sulfate to pleural fluid that stabilizes ADA levels for up to 3 weeks at $37^{\circ} \mathrm{C}$ [7].

The effusion was classified using Light's criteria and albumin gradient as exudative or transudate forms. Cytology in pleural liquid and ADA serum and pleural levels were also evaluated. The results are presented descriptively. The data is shown in the form of Mean \pm Standard Deviation (SD) for the continuous and absolute frequency variables (number/ total number) and the relative frequency (\%) for the categorical variables. Logistic regression was used, with the TB diagnosis dependent variable ( 0 if the patient was not diagnosed with TB, 1 if the patient was diagnosed with TB) and the independent variables (factors) parameters with significant differences between the two groups.

\section{Results and discussions}

The study group comprised 444 patients who were diagnosed with pleural effusion. Cases included 114 (25.6\%) patients confirmed with TB pleural effusion by bacteriological examination (29.8\%), or by histopathological examination (15.9\%) or by any other association of pulmonary parenchymal lesions ( $28.7 \% \%$ ), from which $25.6 \%$ were positive in sputum culture for MTB complex. Controls included 330 patients diagnosed with neoplastic pleural effusions in $146(32.8 \%)$ cases, secondary cardiac pleural effusions in $53(11.9 \%)$ cases, parapneumonic effusions in $43(9.6 \%)$ and $88(19.8 \%)$ cases of other causes (viral, secondary abdominal disorders, non-neoplastic systemic diseases, etc.). In double MTB-HIV infected patients, pleural TB effusions are frequent and can be related with immune reconstitution disease [11] even in non-HIV immune compromised patients [12]. Sometimes, lung tumors can mimic cancer [13] and confusion is greater when TB and lung cancer coexist [14] and pleural effusion occurs [15].

Characteristics of the sex, age, result of biological samples (erythrocyte sedimentation rate (ESR), leukocyte count, neutrophil and lymphocyte count, hemoglobin, fibrinogen in serum and albumin, LDH, and lymphocyte proportion in pleural fluid) are shown in Table 1.

In univariate analysis, patients with TB are mostly males characterized by a lower age, lower blood levels of leucocytes and neutrophils, a lower neutrophil-lymphocyte $(\mathrm{NL})$ rate in blood, and high pleural levels of protein, $\mathrm{LDH}$ and $A D A$, and also an increased number of lymphocytes in pleural fluid (table 2).

There are similar results for demographic characteristics, lower accessibility to pleural biopsy, and the low sensitivity of bacteriological confirmation in pleural fluid for BK culture and significantly higher value of ADA have been reported in other studies [16,17]. In the TB pleural effusion group, the mean pleural fluid ADA was significantly higher compared to non-TB pleural effusion (62.45 IU/L vs. $33.71 \mathrm{IU} / \mathrm{L}$ ). In addition, a multivariate analysis (with all

Table 1

THE DEMOGRAPHIC AND MAIN PARTICULARITIES OF TB PLEURAL EFFUSION COMPARING WITH NON-TB PLEURAL EFFUSION

\begin{tabular}{|c|c|c|c|}
\hline Variable & $\begin{array}{l}\text { Group with TB pleural } \\
\text { effusion } n=114 \\
(25,6 \%)\end{array}$ & $\begin{array}{l}\text { Group without TB } \\
\text { pleural effusion } \\
\mathrm{n}=330(74,4 \%)\end{array}$ & P value \\
\hline Age Mean y, $( \pm$ SD $)$ & $45.23( \pm 18.14)$ & $65.22( \pm 14.43)$ & $<0.0001^{1}$ \\
\hline Gender & & & \\
\hline Male-No. (\%) & $81 / 114(71.05)$ & $221 / 330(66.97)$ & $\mathrm{NS}^{2}$ \\
\hline Female-No. $(\%)$ & $33 / 114(28.95)$ & $109 / 330(33.03)$ & \\
\hline $\begin{array}{l}\text { Total WBC - Mean }( \pm \text { SD) } \\
\text { cells/microL }\end{array}$ & $8.49( \pm 2.51)$ & $9.73( \pm 4.28)$ & $0.0051^{2}$ \\
\hline Limfocytes - Mean ( \pm SD) & $1.97( \pm 0.99)$ & $1.80( \pm 0.86)$ & $\mathrm{NS}^{1}$ \\
\hline Neutrophiles -Mean $( \pm$ SD) & $5.78( \pm 2.34)$ & $6.99( \pm 4.10)$ & $0.0045^{2}$ \\
\hline NL Ratio & $3.49( \pm 2.18)$ & $4.73( \pm 4.29)$ & $0.0050^{2}$ \\
\hline $\begin{array}{l}\text { Hemoglobin }(\mathrm{g} / \mathrm{dl})- \\
\text { Mean }( \pm \mathrm{SD})\end{array}$ & $12.78( \pm 2.14)$ & $12.84( \pm 2.24)$ & $\mathrm{NS}^{1}$ \\
\hline $\begin{array}{l}\text { ESR }(\mathrm{mm} / 1 \mathrm{~h})- \\
\operatorname{Mean}( \pm \mathrm{SD})\end{array}$ & $55.85( \pm 30.16)$ & $45.68( \pm 30.48)$ & $0.0034^{2}$ \\
\hline $\begin{array}{l}\text { Fibrinogen }(\mathrm{mg} / \mathrm{dL})- \\
\text { Mean }( \pm \mathrm{SD})\end{array}$ & $701.52( \pm 330.37)$ & $654.66( \pm 358.57)$ & $\mathrm{NS}^{1}$ \\
\hline Proteins -Mean $( \pm S D)$ & $4.55( \pm 0.78)$ & $3.75( \pm 1.17)$ & $<0.0001^{1}$ \\
\hline Pleural LDH (IU/L) - Mean ( $(S D)$ & $848.09( \pm 542.74)$ & $595.27( \pm 554.89)$ & $0.0001^{1}$ \\
\hline Pleural ADA (IU/L) - Mean $( \pm \mathrm{SD})$ & $62.45( \pm 21.47)$ & $34.06( \pm 18.17)$ & $<0.0001^{1}$ \\
\hline
\end{tabular}

Legend: $T B=$ tuberculosis; $W B C=$ white blood leukocyte counts; $N L$ ratio= neutrophil to lymphocyte ratio; $E S R=$ erythrocyte sedimentation rate; $L D H=$ lactic dehydrogenase; $A D A=$ adenosine deaminase; $S D=$ standard deviation; ${ }^{1}$ Two-Sample Welch Test two-tailed; ${ }^{2}$ Two-Sample $\chi^{2}$ two-tailed 


\begin{tabular}{|l|l|l|l|}
\hline Variable & B & P value & OR [IC95\% for OR] \\
\hline Age & -0.073 & $<0.0001$ & $0.93[0.91$ to 0.94$]$ \\
\hline WBC & -0.097 & 0.006 & $0.91[0.85$ to 0.97$]$ \\
\hline Neutrophils & -0.106 & 0.006 & $0.90[0.83$ to 0.97$]$ \\
\hline Lymphocytes & 0.196 & 0.107 & $1.21[0.95$ to 1.54$]$ \\
\hline NL Ratio & -0.130 & 0.006 & $0.89[0.80$ to 0.96$]$ \\
\hline ESR & 0.011 & 0.004 & $1.011[1.004$ to 1.018$]$ \\
\hline Proteins & 0.841 & $<0.0001$ & $2.13[1.74$ to 3.07$]$ \\
\hline Pleural LDH & 0.001 & $<0.0001$ & $1.002[1.001$ to 1.003$]$ \\
\hline Pleural ADA (IU/L) & 0.068 & $<0.0001$ & $1.07[1.05$ to 1.09$]$ \\
\hline
\end{tabular}

Legend: $W B C=$ white blood leukocyte counts; $N L$ ratio= neutrophil to lymphocyte ratio;

$E S R=$ erythrocyte sedimentation rate; $L D H=$ lactic dehydrogenase; $A D A=$ adenosine deaminase

Table 2

LABORATORY RESULTS FOR PLEURAL FLUID ANALYSIS

\begin{tabular}{|l|c|c|c|}
\hline Variable & B & P value & OR [IC95\% for OR] \\
\hline Age & -0.057 & $<0.0001$ & $0.94[0.92$ to 0.96$]$ \\
\hline WBC & -0.174 & 0.01 & $0.84[0.76$ to 0.92$]$ \\
\hline Pleural ADA & 0.057 & $<0.0001$ & $1.05[1.04$ to 1.07$]$ \\
\hline
\end{tabular}

Tabel 3

ADA PLEURAL VERSUS AGE AND WBC

Legend: $W B C=$ white blood leukocyte counts; $A D A=$ adenosine deaminase

the factors that had significance or were marginally insignificant) was used, the algorithm being backward selection, the final model being reproduced in table 3 .

In the multivariate model, the following predicted factors remain age (a younger age increases the probability of TB), WBC (a smaller number of WBC increases the probability of TB) and the level of pleural ADA (an increased pleural ADA increases the likelihood of TB). The model correctly classified $84 \%$ of patients with a specificity of $80 \%$ and a sensitivity of $85 \%$.

The ROC analysis (receiver operating characteristic) for ADA is shown in figure 1.

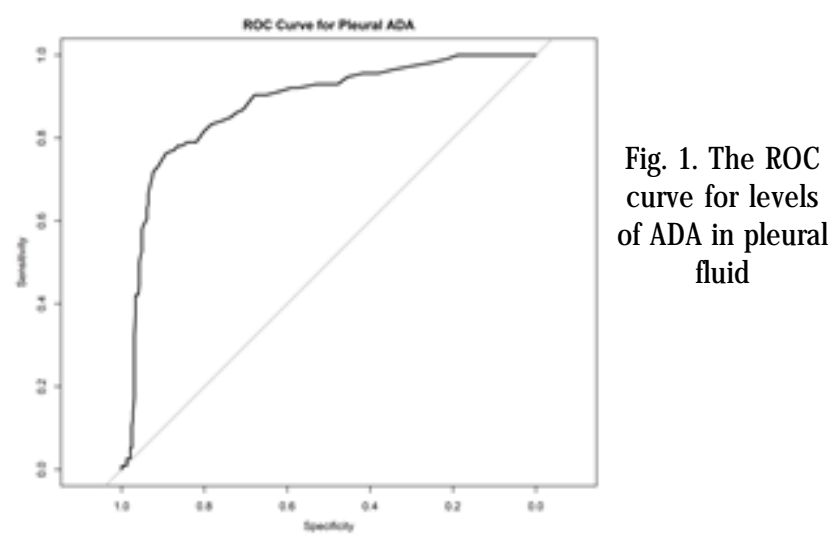

The receiver-operating curve (ROC) for ADA was performed and the area under curve (AUC) was $0.876(95 \%$ $\mathrm{Cl}$ 0.842-0.917) (fig. 1, tabel 4).

Tabel 4

AREA UNDER CURVE FOR LEVELS OF ADA IN PLEURAL FLUID

\begin{tabular}{|c|c|}
\hline AUC & C195\% for AUC \\
\hline 0.8796 & 0.842 to $0.917, \mathrm{p}<0.00001$ \\
\hline
\end{tabular}

An ideal cut-off value is one that produces a specificity of 0.95 ( 1 - specificity of 0.05 ) butalso a good sensitivity. In our study population, the ADA value of $55.50 \mathrm{IU} / \mathrm{L}$ appears at an optimal value, and as a useful tool for diagnosis of TB pleural effusion.

Our research supports data found in the medical literature aboutADA value in pleural fluid as the predictive tool of the etiologic diagnosis of tuberculosis. However, there are important differences in choosing optimal cutoff values for ADA activity in pleural fluid. In the study of Kawamatawong, on 178 patients from Thailand, the best cut-off pleural fluid ADA level was $30 \mathrm{IU} / \mathrm{L}$ (sensitivity of $82 \%$ and specificity of $91 \%$ ) [18]. Although we have found that $55 \mathrm{IU} / \mathrm{L}$ should be used, a value of $40 \mathrm{IU} / \mathrm{L}$ remains the commonly accepted cut-off for TB pleural effusion diagnosis with a $79 \%$ sensitivity and $79 \%$ specificity in Metha study [19-21]. Other studies showed a low specificity for this value and found that LDH/ADA ratio at a cut-off level of 16.20 could be highly predictive for TB pleural effusion [18]. If we increase it, the cut-off value of ADA will increase specificity but will decrease sensitivity [21]. However, the meta-analysis published by Xuwei Gui, which reviewed the results of 12 studies, found that $A D A \geq$ $50 \mathrm{U} / \mathrm{L}$ can help as a biomarker for TB pleural effusion, and this value is closer to ours [22]. We need to keep in mind that the high ADA value could have false positive interpretation because it could be found in empyema, lymphoma or other malignant condition with associated lymphocytic pleural effusion [23]. Finding a relevant cutoff value would allow a more rapid and less invasive differential diagnosis with malignant diseases [24].

However, interpreting an ADA value in sustaining a positive diagnosis of TB pleural effusion appears to be dependent on the prevalence of the disease in that region. For example, a high value of ADA in Romania is suggestive of TB, but in endemic areas for mycoses such as coccidioidomycosis and histoplasmosis, the same value of ADA can have a different interpretation [25, 26]. More studies will be requested to determine the influence of age or other factors on ADA value for the patients diagnosed with TB pleural effusion.

Sensitive biomarkers are needed, particularly in a country in which mortality caused by TB remains high [27]. An early diagnosis and treatment, before the disease expands, smoking cessation [28] might be curative and will assure a better quality of life. A systematic review [29] found that, beside the direct effect on physical activity, TB also creates a psychological distress, difficulties for occupational reinsertion and economic status deterioration, as found in other chronic pulmonary disease [30]. All these might be prevented by a rapid, affordable and sensitive diagnostic test. 


\section{Conclusions}

Using ADA value is beneficial in the diagnosis of TB pleural effusion, being a simple, cheap, accessible method in a country where the TB incidence is high, as in Romania. A value higher than $55 \mathrm{IU} / \mathrm{L}$ in the context of young people, with exudative, Iymphocytic pleural effusion, and exclusion of other disorders, could be sufficient for starting the treatment if other pathognomonic criteria are missing.

Acknowledgment : We gratefully thank to all patients and medical staff who participated in this study.

\section{References}

1.LABORIN, R.L. Chest. 127, nr. 2, 2005, p. 417.

2.LIGHT RW. Pleural diseases. 3rd ed. Baltimore, MD: William \& Wilkins, 1995, p.154.

3.NITU, F.M., OLTEANU, M., STREBA, C.T., JIMBOREAN, G., POSTOLACHE, P., MAN M.A., TROFOR,A.C., NEMEa , R.O., DRAGONU, L., OLTEANU, M., Rom. J. Morphol .Embryol., 58, nr. 2, 2017, p. 385. 4.MAN, M.A., NITU, M.F., STRAMBU, L., FLORESCU, C., STREBA, C.T., TROFOR, A.C., Rom. J. Morphol. Embryol., 57, nr.1, 2016, p. 237 5.BOONYAGARS, L., KIERTIBURANAKUL, S., J. Infect. Dis. Antimicrob. Agents. 27, 2010, p.111.

6.ROTH BJ. Chest. 116, nr 1, 1999, p. 97.

7.*** Adenosine deaminase assay kit package insert. Diazyme Laboratories, catalogue number: DZ117A-K. http://www.diazyme.com/ adenosine-deaminase-ada

8.KATARIA, Y.P., KHURSHID, I. Chest. 120, nr. 2, 2001; p. 334.

9.J IMENEZ CASTRO, D., DIAZ NUEVO, G., PEREZ-RODRIGUEZ, E., LIGHT, R.W. Eur. Respir. J., 21, nr.2, 2003, p. 220.

10.SONG, D., LUN, A.R., CHIU, W. NZJ Med Lab Science. 64, 2010, p. 11.

11.KORTZIS, V., ATHANASIOU, G., ARGHIR, I., DANTES, E., CAMBREA, S., POSTOLACHE, P., ARGHIR, O. CHEST 145 (3 Meeting Abstracts), 2014; 87A; Doi: 10.1378/chest.1825039.

12.MAN, M.A., ARGHIR, O.C., MAN, S., STREBA, C.T., OLTEANU, M., NITU, M. Rom. J. Morphol. Embryol., 55, nr. 2, 2014; p. 453.
13.CAMBREA, S.C., RESUL, G., BULBUC, I., CAMBREA, M., VASILESCU, F., Rom. J. Morphol. Embryol., 55, nr. 2, 2014; p. 407.

14.POSTOLACHE P., NEMES RM., PETRESCU O., MERISANU IO. Medical -Surgical -J ournal, 119, nr.1, 2015, p. 77

15.DELEANU, O., NEBUNOIU, A-M., ULMEANU, R., MIHALTAN, F., ARGHIR, 0. CHEST. 144 (4_Meeting abstracts); 2013; 214A. Doi:10.1378/ chest 1704616

16.XU, H.Y, LI, C-Y, SU, S-S., YANG, L., YE, M., YE, Y.-R., PEI-PEI, KE., CHEN, C.-S., XIE, X.-P., LI, Y.-P. Medicine, 96, nr. 47, 2017, e8412.

17.TAY, T.R., TEE, A. BMC Infect. Dis., 13, 2013, p. 546.

18.KAWAMATAWONG, T., PANOMPONG, K., KIATBOONSRI, S., KHUPULSUP, K., Chest, 134, 2008, 55001S.

19.WANG, J., JUN LIU, J., XIE, X., SHEN, P., E, J ., ZENG, Y. BMC Pulm. Med., 17, 2017, p. 168.

20.LIANG, Q.L., SHI, H.Z., WANG, K., QIN, S.M., QIN, X., J. Respir, Med., 102, 2008, p.744.

21.MEHTA, A.A, GUPTA, A.S., AHMED, S., RAJESH, V. Lung India., 31, nr. 2, 2014, p. 142.

22.XUWEI, G., HEPING, X. Int J Clin Exp Med., 7, nr. 10, 2014, p. 3126. 23.ERNAM, D., ATALAY, F., HASANOGLU, H.C., KAPLAN, O., Clin. Biochem., 38, 2005, p.19.

24.RASCU, A., NAGHI, E., OPELEA, M.R., NIPU, F.M., ARGHIR, O.C., Rom. J. Morphol. Embryol. 57, nr 3, 2016; p.1171.

25.MARICA, C., DIDILESCU, C., TANASESCU, M., SOCACI, A., NINI, G., MAHLER, B., Eur Respir J., 42, Suppl. 57, 2013; e3760.

26.VORSTER, M., ALLWOOD, B., DIACON, A., KOEGELENBERG, C., J. Thorac. Dis., 7 nr. 6, 2015, p. 981.

27.ARGHIR, O.C., DANTES, E., OTELEA, M., RASCU, A., BORGAZI, E., CAMBREA, S.C., Rom. J. Leg. Med., 26, nr. 2, 2018; p.187.

28.IANOSI, E.S., POSTOLACHE, P., MACOVEI, L.A., SZATHMARY, M., SZASZ, S., NEMES, R.M., JIMBOREAN, G., Rev Chim. (Bucharest) 69, no 7, 2018, p.1766

29.CHANG, B., WU, AW., HANSEL, NN., DIETTE, GB., Quality of Life Research 13, nr. 10, 2004, p. 1633.

30.OTELEA, M.R, ARGHIR, O.C., ZUGRAVU, C., NAGHI, E., ANTONIU, S., RASCU, A. Rev. Chim. (Bucharest). 69, no. 2, 2018; p. 346.

Manuscript received: 26.08 .2018 